\title{
Pharmacognostic investigations of Achyranthes aspera Linn.
}

\author{
Research article
}

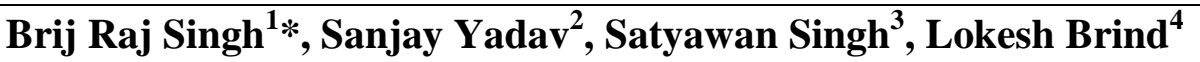 \\ 1. M.Pharm faculty, 2. Assistant Professor, 3. Director Pharmacy, 4. M.Pharm faculty \\ Division of Pharmacognosy, Saroj Institute of Technology and Management, Lucknow, U.P.
}

\begin{abstract}
Aims \& objective: Some pharmacognostical investigations were carried out on the leaves, stems and roots of Achyranthes aspera Linn to record parameters for identifying and differentiating various species of Achyranthes.

Methods: The research specimens were authenticated and preserved both in fresh and dry forms. The leaves and stems were morphologically screened followed by anatomical studies with the aid of Labphot 2 microscopic units. Powder microscopy and micrometric studies, including leaf constants, were performed using suitable tools and reagents under different magnifications.

Important observations and results: The leaves were petiolate and opposite, decussate, elliptic-obovate, acute apex with decurrent base, abaxial surfaces which turned blackish on storage, and had irritant smell with a slightly bitter taste. The vein islets were squarish and polygonal. Covering and glandular trichomes; anisocytic and anomocytic stomata were evident. Anomalous secondary growth of xylem and phloem in stem and roots; Vessels were helical, spiral and pitted; rosette shaped calcium oxalate crystals were also evident.
\end{abstract}

Key words: Pharmacognostic investigations; Achyranthes aspera; Rosette; Anisocytic; Stone cells; Anomocytic

\section{Introduction}

Amaranthaceae is a cosmopolitan family consisting of 64 genera and about 800 species, mostly abundant in tropical regions of America, Africa, and India (1). The family represented by herbs and few shrubs, contains most of the important allergic species (2, 3). Achyranthes aspera Linn, Family: Amaranthaceae or its common name Apamarga is a stiff, erect

\section{*Corresponding author}

\section{Brij Raj Singh}

Division of Pharmacognosy,

Saroj Institute of Technology and

Management, Lucknow, U.P.

Email-brijraj.pharma@gmail.com herb, found commonly as a weed throughout India up to an altitude of $900 \mathrm{~m}$. the drug goes well with the name Apamarga but the nighantus mention a red variety also, called Raktapamargh and the latter is equated with Achyranthes bidentata B1., by some authors. The red variety possesses red pigments in the epidermis and outer cortex of the stem while in other respects the anatomical features are alike in both the forms (4). The nature of chemical constituents (steroids and triterpenoids) is also similar in both the varieties. Another plant belonging to the Amaranthaceae family is Cyathula prostrata (Linn.) Blume., also gets substituted for $A$. aspera (5). The plant has been mentioned in manuscripts of Ayurveda and Chinese medicines. The plant has been reported to 
possess a number of medicinal properties (6).

Based on the foregoing, the present study entails the pharmacognostic investigation of the whole plant of Achyranthes aspera Linn., with a view of providing pertinent information/data on its identification.

\section{Materials and methods \\ Collection of species}

Achyranthes aspera Linn were collected in the month of October, from local place of the Allahabad district and were authenticated by Dr. Alok Lahri Incharge, CIF Division N.B.R.I., Lucknow, U.P., India (Ref. no. NBRI/CIF/182/2010). A voucher specimen (VE131) was deposited in the herbal museum at Saroj Institute of Technology and Management, Lucknow, Uttar Pradesh. Care was taken to select healthy plants for the study. The whole parts of plant for the study were collected fresh from the plant and placed in FAA (formalin: acetic acid: $70 \%$ ethyl alcohol) in a ratio of 1:1:18. Twenty four hours later, the specimens were dehydrated with a graded series of tertiary-butyl alcohol (TBA).

\section{Sectioning}

Fresh potato pieces were used to support (pith) soft tissues while sectioning. Liquid was kept on the single -edge razor blade, so that the sections float as they get cut. A large number of slices were cut rapidly, and best ones were sorted out. Wherever necessary, sections were stained with safranin. Glycerin mounted temporary preparations were made for macerated/cleared materials. Powdered materials of different parts were cleared with $\mathrm{NaOH}$ and mounted in glycerin after staining with safranin. Different components were studied and measured as indicated below $(7,8)$.

\section{Microscopic examination}

With the aid of a compound microscope (Focus (ISI), JPM-1, India and Olympus microscope) and an eye-piece micrometer calibrated with a stage micrometer, the individual character of each specimen was studied under both low- (10x $\times 10 x)$ and high-power $(10 x \times 45 x)$ magnification.

\section{Powder microscopy}

The leaves were dried for a minimum of 15 days under a shade, powdered and screened through sieves with aperture size of $180 \mu \mathrm{m}$ and $125 \mu \mathrm{m}$ separately to obtain fine and very fine powders, respectively, and then subjected to microscopic examination. The specimens were treated with the following reagents in order to evaluate components of diagnostic value: $50 \%$ glycerin as temporary mountant; $2 \%$ phloroglucinol in a mixture of $90 \%$ ethanol and conc. $\mathrm{HCl}(1: 1)$ for lignin (7).

\section{Micrometric studies}

Micrometric evaluation (including assessment of leaf constants) was carried out with the aid of a compound microscope fitted with a camera (Swift Ive's) as described elsewhere $(8,9,10)$.

\section{Study, observations and results \\ Macroscopic characteristics of leaves, stems and roots}

The leaves were of opposite, petiolate, decussate, elliptic-obovate, acute and with decurrent base. The dried leaves were yellowish green above and pale green below; midrib raised below and flat above; about $4-7$ pairs of primary venations, extended up to the margin; the petiole cylindrical being $0.6-1 \mathrm{~cm}$ long and $0.3-1$ $\mathrm{mm}$ wide. The leaves were $2.5-5.2 \mathrm{~cm}$ in length and $1.5-4 \mathrm{~cm}$ in width. The adaxial surface was smooth and slippery unlike the 
abaxial side. The dried leaves had a characteristics odour and were slightly mucilaginous in taste. Some leaves on storage turned blakish on their adaxial surface.

The stems were of cylindrical, branched, solid, yellowish-brown, noxious odour, hairy surface. The stem, which measured more than $1 \mathrm{~cm}$ in thickness, showed central brown pith.

The roots were of tap root, cylindrical, yellowish-brown, and sweet in taste, $0.1-1 \mathrm{~cm}$ thickness, presence of secondary and tertiary root \& root scars.

\section{Microscopy of petioles and leaves}

The petiole has a crescent shaped, thick cuticle, covering Trichome, single layered epidermis; ground tissues consisting of thin -walled parenchymatous cells containing calcium oxalate crystals; 3 vascular bundle situated in mid region (Figure1)

The leaves have covering and glandular tichomes, slightly straight walled single layered upper epidermis and wavy walled single layered lower epidermis. Both the adaxial and abaxial is stomatiferous. Stomata type is anisocytic and anomocytic and distinct subsidiary cells are evident.3-5 layered collenchymas on upper side and 2-3 layered on lower side. Ground tissue consisting of thin layered parenchymatous cells having 3 vascular bundles; crystals of calcium oxalate found scattered in ground tissues (Figure2, 3, 4).

\section{Stem}

The stem is cylindrical. It has 5-10 prominent ridges; epidermis single layered, covered by thick cuticle having uniseriate, 2-3 celled, covering trichomes. Cortex 4-8 layered, composed of parenchymatous cells, most of them containing calcium oxalate crystals. Thin walled cork cells; pericycle a discontinuous ring of lignified fibres. The cortical zone is wide with uniform width, vascular tissues show anomalous secondary growth having incomplete ring of xylem and phloem; cambial strip present between secondary xylem and phloem; vessels helical, spiral and pitted. The pith is wide having oval to polygonal parenchymatous cells (Figure 5).

\section{Root}

The roots have 3-5 layered, rectangular, elongated, thin walled cork cells. Secondary cortex were shows 6-8 layers, oval,thin- walled, parenchymatous cells having groups of stone cells and 6 discontinuous rings of anomalous secondary thickening composed of vascular tissues. Medullary rays 1-3 cells wide. Calcium oxalate crystals present in cortical region as well as medullary rays (Figure 6).

\section{Powder characteristics Leaf powder}

Fragments of leaf are found in the powder. They exhibit certain specific characters of diagnostic values. Two types of epidermal trichomes were observed with powder. They are uniseriate, multicellular covering Trichome having width 16-24 $\mu \mathrm{m}$ and with globular head, multistalk glandular trichomes. Rosette shaped calcium oxalate crystals were also found having dimensions 1.67-6.67 $\mu \mathrm{m}$.

\section{Stem powder}

The stem powder contains lignified fibres, thin walled cork cells, helical and pitted vessels (Figure 7). 


\section{Leaf surface data}

Leaf surface data are tabulated in table 1 .

Table 1: Micrometrics of the leaves of Achyranthes aspera

\begin{tabular}{lc}
\hline Numerical data & leaf \\
& Min-mean- max \\
\hline Stomatal index (lower surface) & $16.66-17.85-20$ \\
Stomatal index (upper surface) & $7.69-8.33-9.09$ \\
Vein-islet number & $10-11.66-13.33$ \\
Vein-termination number & $10-13.33-16.66$ \\
Palisade ratio & $7-9-11$ \\
Glandular trichome (diameter in $\mu \mathrm{m})$ & $16-20-24$ \\
\hline
\end{tabular}

\section{Discussion}

The main objective of the current study was to evaluate the whole plant of Achyranthes aspera pharmacognostically in order to obtain and record some reproducible and precise parameters for the plants since the phytochemical constituents and pharmacological potential of the species have been reported in the literature.

\section{Conclusion}

The pharmacogno - anatomical and powder characteristics of the leaf stem and root of a plant may be useful in identifying plant species in whole and powder form.

\section{References}

1. Lawerence GHM.Taxonomy of vascular plants. New Yark; Macmillan Publ. Co; 1989.

2. Lewis WH., Vinay P., Zenger VE. Airborne and Allergic Pollen of North America, London. Baltimore; Johns Hopkins Univ Press; 1983.

3. Woodhouse R. P, Antigenic Analysis by Gel Diffusion, III, Pollens of the Amaranth- Chenopod Group. Ann. Allergy, 1957; 15; 527-536.
4. Prasad S, Bhattacharya I.C, Pharmacognostical studies on Achyranthes aspera. J. Sci. Industr. Res. 1961; 20C; 246.

5. Sivarajan V. V, Balachandran I, Ayurvedic Drugs and their Plant Sources. New Delhi; Oxford and IBH Publishing Co. Pvt. Ltd; 1994; 47p.

6. Dwivedi S, Dubey R, Mehta K, Achyranthes aspera Linn. (Chirchira): A Magic Herb in Folk Medicine. Ethnobotanical Leaflets. 2008; 12; 670676.

7. Khandelwal K. R, Practical Pharmacognosy Techniques and Experiments. India; Nirali Prakashan; 2006; 15- 163p.

8. Evans W. C, Text Book of Pharmacognosy. 15ed. London; W.B. Saunders; 2002; 516-545p.

9. Lala P.K, Practical Pharmacognosy. India; Lina Guha Publication; 1981; 136-153p.

10. Wallis T.E, Text Book of Pharmacognosy. 5ed. New Delhi, India; CBS Publishers and Distributors; 2005; 559-618p. 


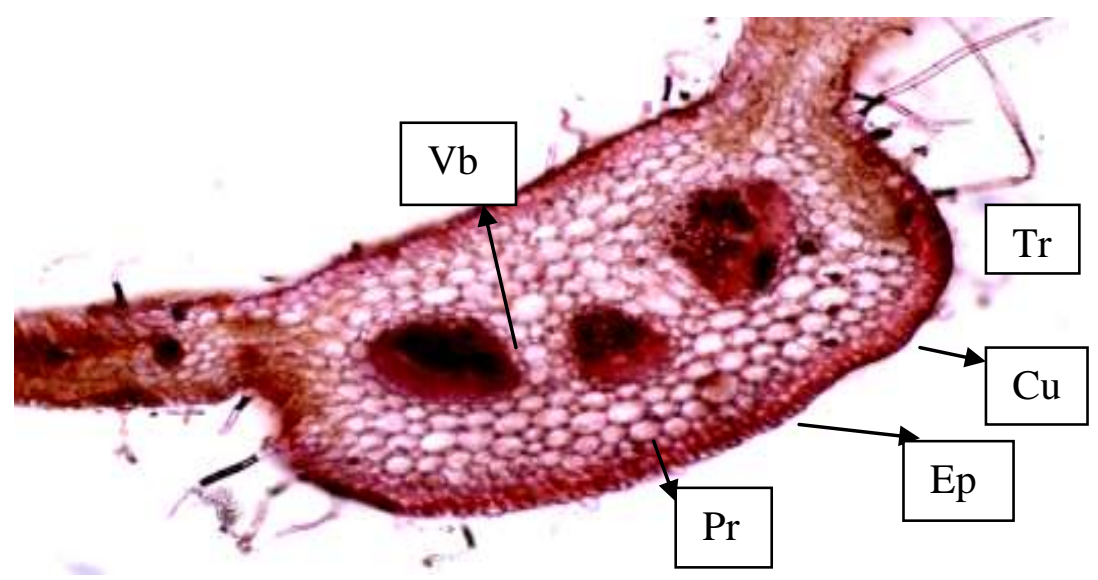

Figure 1: Anatomy of petiole- Transverse section of petiole (entire view) (Ep= Epidermis; $\mathrm{Cu}=$ Cuticle; $\mathrm{Tr}=$ Trichome; $\mathrm{Vb}=$ Vascular bundles; $\mathrm{Pr}=$ Parenchymatous cells)

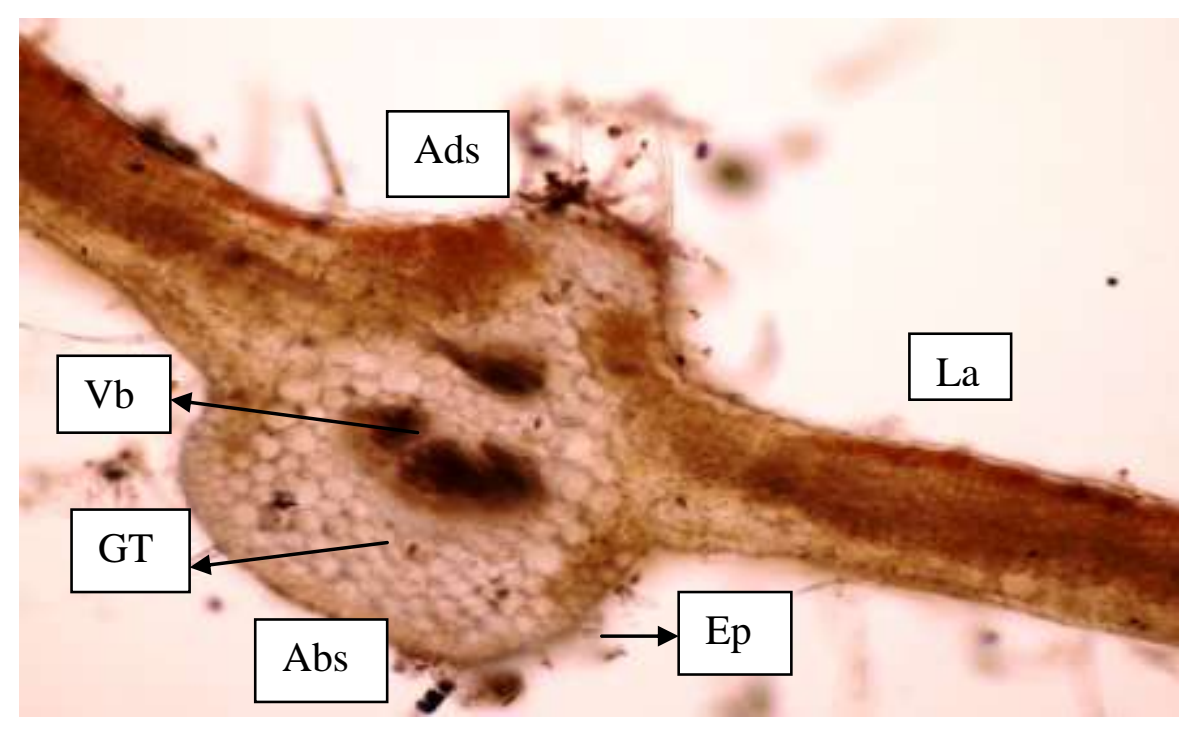

Figure 2: Anatomy of leaves - Transverse section of leaves through midrib (entire view) $($ Ep=Epidermis; Abs= Abaxial side; Ads= Adaxial side, $G T=$ Ground tissue; $V b=$ Vascular bundles; La= Lamina) 


\section{Brij Raj Singh et.al, Pharmacognostic investigations of Achyranthes aspera Linn.}
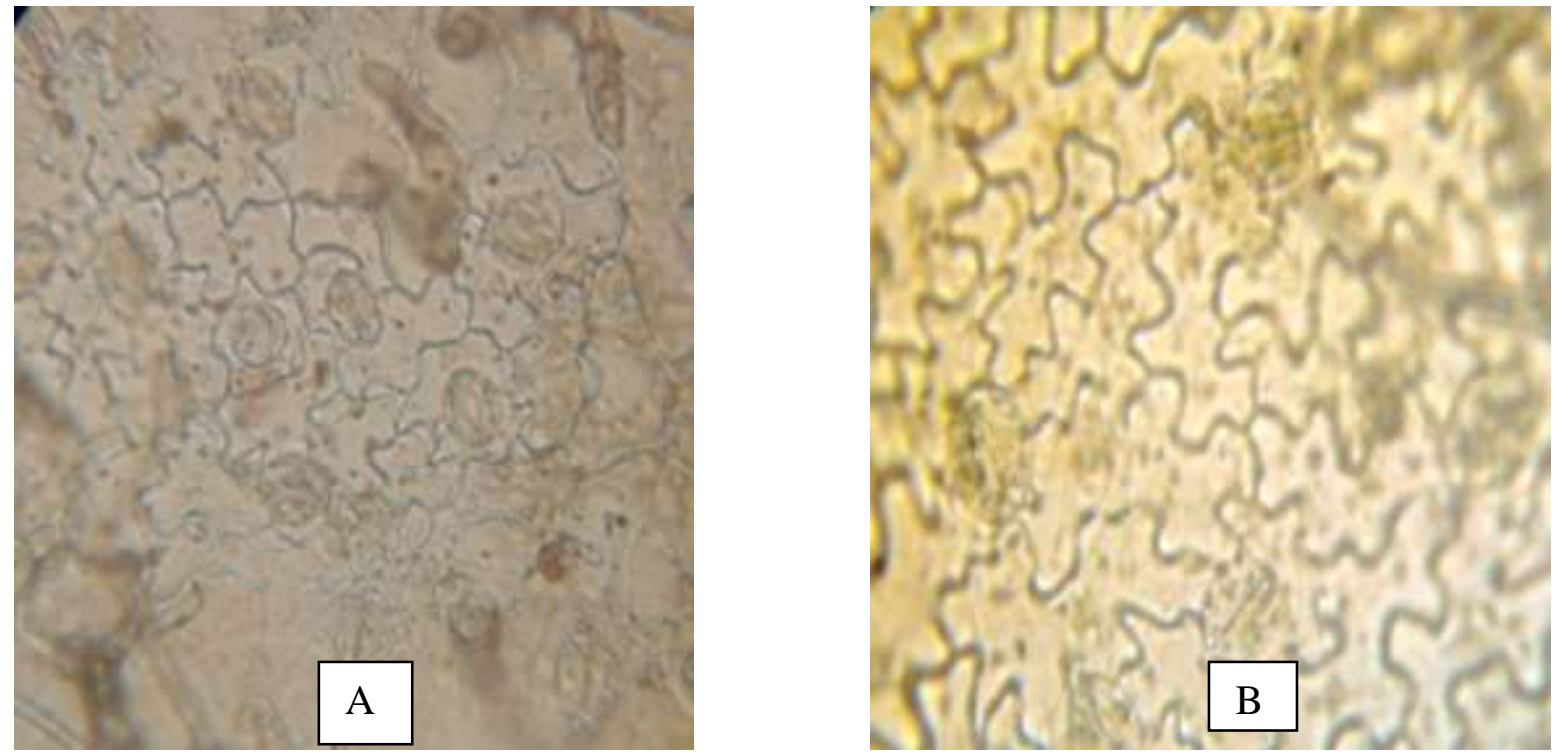

Figure 3: $A=$ slightly straight walled upper epidermis $B=$ Wavy walled lower epidermis
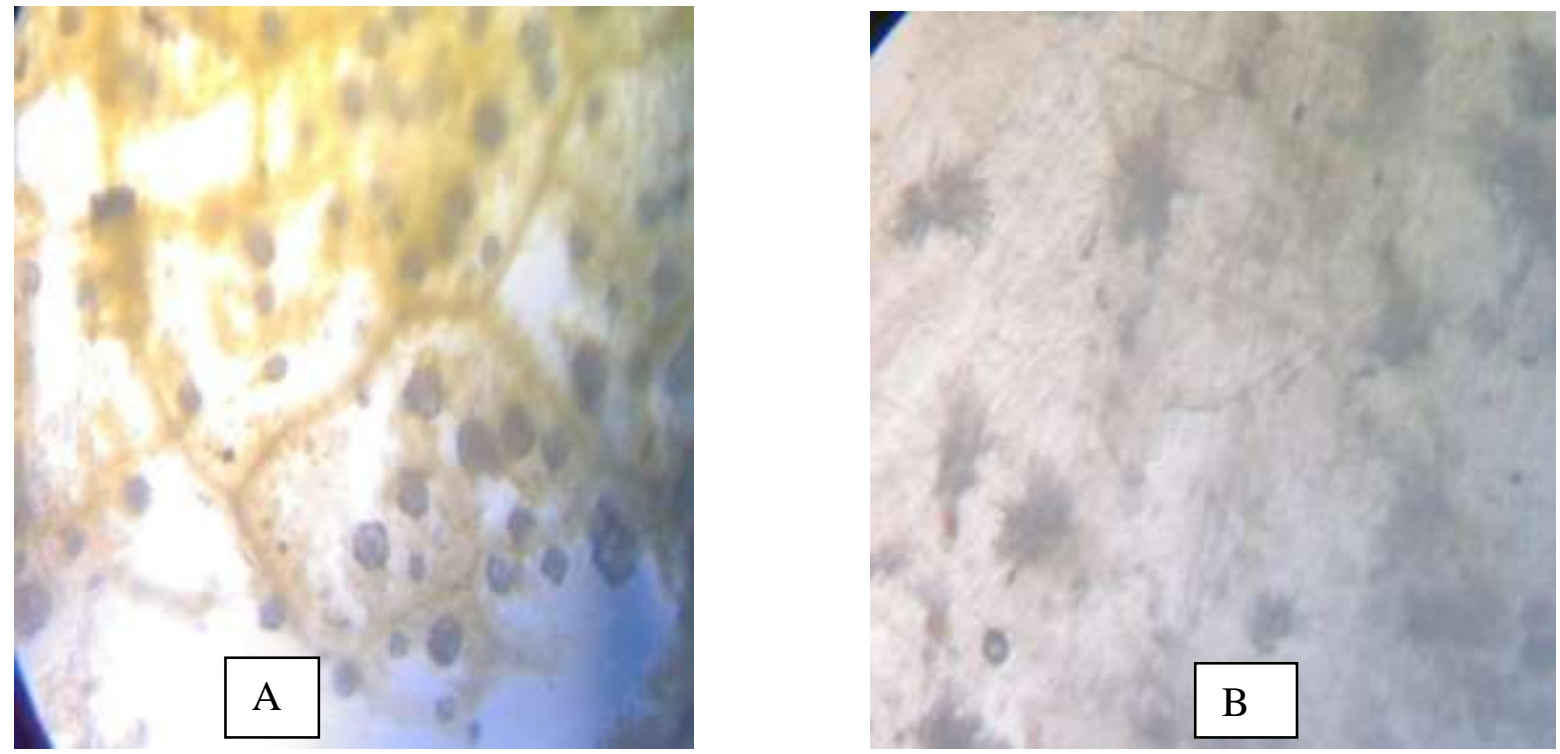

Figure 4: Calcium oxalate crystals; $A=$ before conc. Sulphuric acid treatment $B=$ after conc. Sulphuric acid treatment 


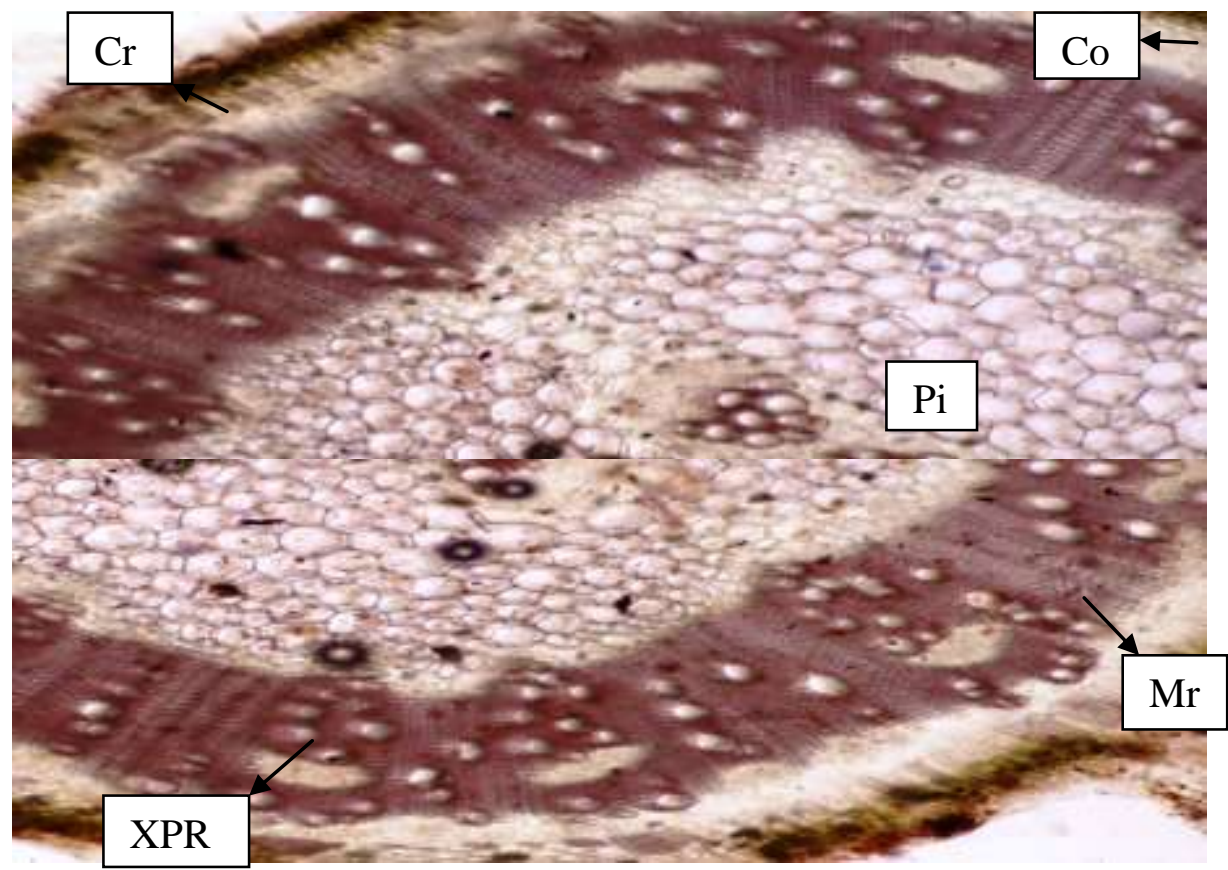

Figure 5: Anatomy of stems-A sector of the transverse section of stem $(\mathrm{Co}=\mathrm{Cortex} ; \mathrm{Cr}=$ Cork cells; $\mathrm{Pi}=\mathrm{Pith} ; \mathrm{Mr}=$ Medullary rays; $\mathrm{XPR}=\mathrm{Xylem}$ and $\mathrm{Phloem}$ ring)

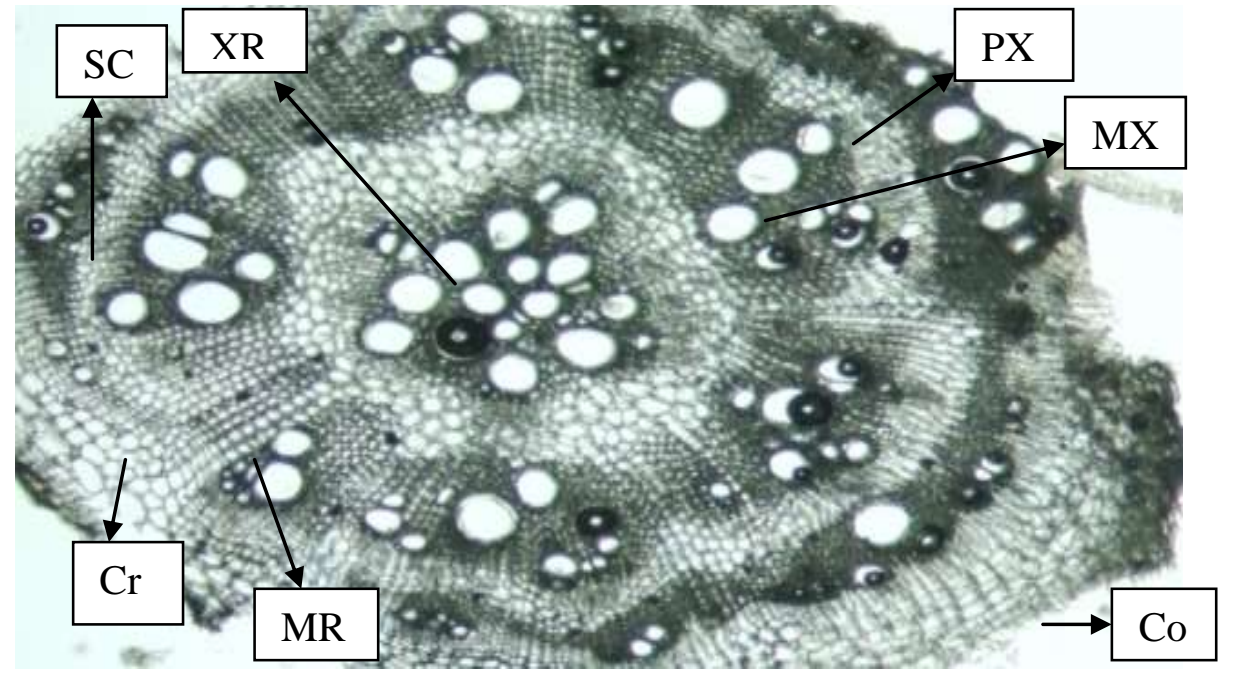

Figure 6: Anatomy of roots - Transverse section of root (entire view) $(\mathrm{Co}=\mathrm{Cork}$; $\mathrm{Cr}=$ Cortex; $\mathrm{MR}=$ Medullary rays $\mathrm{SC}=$ Stone cells; $\mathrm{XR}=$ Xylem ring; $\mathrm{PX}=$ Protoxylem; $\mathrm{MX}=$ Metaxylem) 

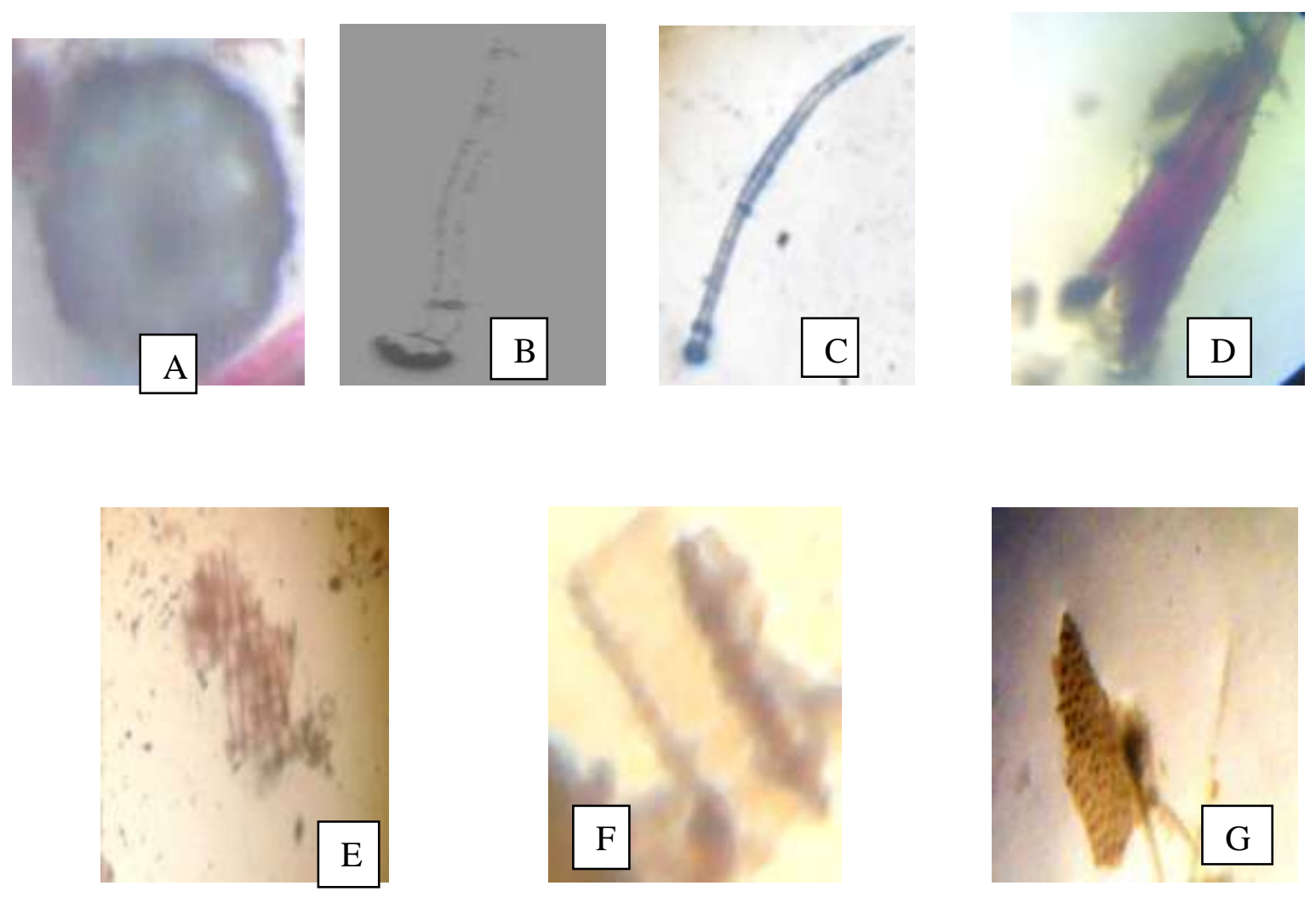

Figure 7: Powder characteristics $(\mathrm{A}=$ Rosette shape calcium oxalate crystal, $\mathrm{B}=$ Glandular Trichome, $\mathrm{C}=$ Covering Trichome, in leaf; $\mathrm{D}=$ Lignified fibre, $\mathrm{E}=$ Cork cells, $\mathrm{F}=$ Helical vessels, $\mathrm{G}=$ Pitted vessels, in stem) 